\title{
PENINGKATAN PEMANFAATAN RANSUM PADA AYAM SENTUL YANG DIBERI EKSTRAK BUAH MENGKUDU ( Morinda citrifolia) DENGAN SUPLEMENTASI TEMBAGA DAN SENG
}

\section{Increased Feed Utilization In Sentul Chicken Fed With Noni Fruit Extract (Morinda citifolia) Supplemented With Copper And Zinc}

\author{
Tyara Rahayuni Nur Azizah ${ }^{1}$, Dimas Prasetyo Singgih ${ }^{1}$, Hendi Setiyatwan ${ }^{2}$, Tuti \\ Widjastuti $^{2}$, Indrawati Yudha Asmara ${ }^{2}$ \\ ${ }^{1}$ Program Sarjana Ilmu Peternakan, \\ Fakultas Peternakan Universitas Padjadjaran, Universitas Padjadjaran \\ Kampus Jatinagor, Jl. Raya Bandung-Sumedang KM.21, Jatinangor-Sumedang, \\ Jawa Barat 45363 \\ ${ }^{2}$ Fakultas Peternakan, Universitas Padjadjaran, Bandung
} Kampus Jatinangor, J1. Raya Bandung-Sumedang KM.21，Jatinangor-Sumedang, Jawa Barat 45363

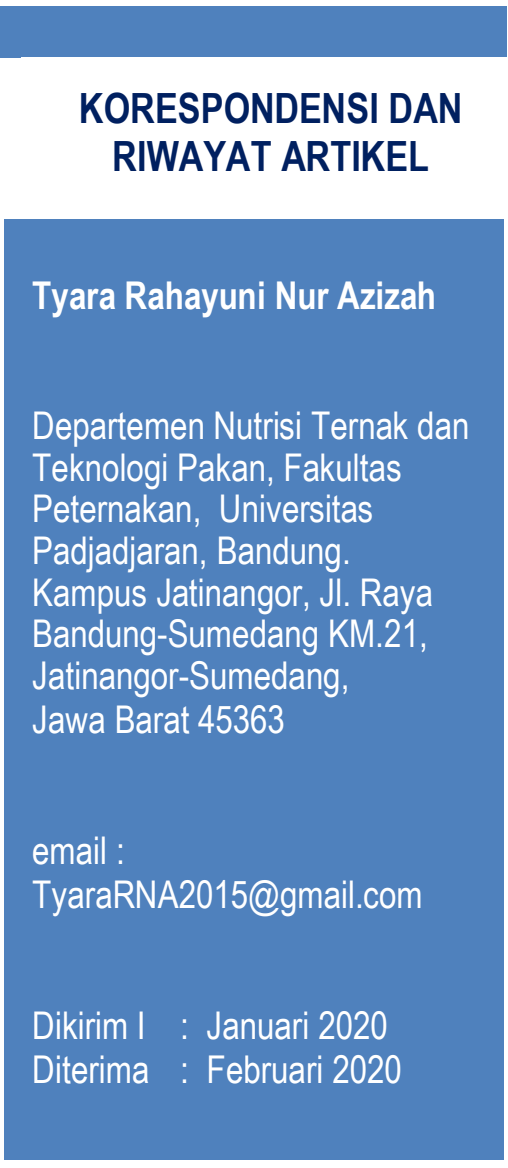

\begin{abstract}
ABSTRAK
Penelitian telah dilaksanakan di Kandang Test Farm, Laboratorium Nutrisi Ternak Ruminansia dan Kimia Makanan Ternak Fakultas Peternakan Universitas Padjadjaran. Tujuan penelitian adalah mengetahui tingkat penambahan ekstrak buah mengkudu yang disuplementasi mineral tembaga dan seng yang menghasilkan kecernaan protein, bahan kering, bahan organik, nilai energi metabolis, dan retensi nitrogen paling tinggi. Seratus ekor DOC (Unsexed) yang dipelihara selama 12 minggu, dialokasikan ke dalam rancangan acak lengkap dilanjut Uji Jarak berganda Duncan dengan lima perlakuan dan diulang sebanyak lima kali. Kombinasi ransum penelitian terdiri atas: ransum basal (P0), P0 + ekstrak mengkudu $50 \mathrm{mg} / \mathrm{kg}$ ransum yang disuplementasi mineral $\mathrm{CuSO}_{4}$ dan $\mathrm{ZnO}(\mathrm{P} 1)$, $\mathrm{P} 0+$ ekstrak mengkudu $150 \mathrm{mg} / \mathrm{kg}$ ransum yang disuplementasi mineral $\mathrm{CuSO}_{4}$ dan $\mathrm{ZnO}(\mathrm{P} 2), \mathrm{P0}+$ ekstrak mengkudu $250 \mathrm{mg} / \mathrm{kg}$ ransum yang disuplementasi mineral $\mathrm{CuSO}_{4}$ dan $\mathrm{ZnO}(\mathrm{P} 3), \mathrm{P0}+$ ekstrak mengkudu $350 \mathrm{mg} / \mathrm{kg}$ ransum yang disuplementasi mineral $\mathrm{CuSO}_{4}$ dan $\mathrm{ZnO}(\mathrm{P} 4)$. Hasil analisis statistik menunjukan bahwa penambahan ekstrak buah mengkudu yang disuplementasi mineral tembaga dan seng nyata meningkatkan nilai kecernaan protein, bahan kering, bahan organik, nilai energi metabolis,
\end{abstract} dan retensi nitrogen pada ayam Sentul. Disimpulkan bahwa penambahan ekstrak buah 
mengkudu $250 \mathrm{mg} / \mathrm{kg}$ ransum yang disuplementasi mineral $\mathrm{CuSO}_{4}$ dan $\mathrm{ZnO}$ meningkatkan kecernaan dengan nilai kecernaan protein $67,52 \%$, kecernaan bahan kering 70,12\%, kecernaan bahan organik $75,14 \%$, nilai energi metabolis $3460,79 \mathrm{kkal} / \mathrm{kg}$, dan retensi nitrogen dengan penambahan ekstrak buah mengkudu $150 \mathrm{mg} / \mathrm{kg}$ ransum yang disuplementasi $\mathrm{CuSO}_{4}$ dan $\mathrm{ZnO}$ $81,45 \%$.

Kata Kunci: mengkudu, kecernaan, ransum

\section{ABSTRACT}

The research was carried out on February 21 to May 16, 2019 at Kandang Test Farm, Ruminant Animal Nutrition and Chemistry Nutrition Laboratory, Faculty of Animal Husbandry, Padjadjaran University. The purpose of this study was to determine the level of addition of noni fruit extract supplemented with copper and zinc minerals that produced protein digestibility, dry matter, organic matter, the highest metabolic energy value, and nitrogen retention. One hundred DOC (Unsexed) tails that were kept for 12 weeks were allocated into a complete randomized design followed by Duncan's multiple range test with five treatments and repeated five times. The combination of research rations consisted of: basal ration (PO), $P 0+$ noni extract $50 \mathrm{mg} / \mathrm{kg}$ ration supplemented with $\mathrm{CuSO} 4$ and $\mathrm{ZnO}(P 1)$ minerals, $\mathrm{PO}+$ noni extract $150 \mathrm{mg} / \mathrm{kg}$ ration supplemented with $\mathrm{CuSO} 4$ and $\mathrm{ZnO}(\mathrm{P} 2)$ minerals; $\mathrm{PO}+$ noni extract $250 \mathrm{mg} / \mathrm{kg}$ ration supplemented with minerals $\mathrm{CuSO} 4$ and $\mathrm{ZnO}(\mathrm{P3}), \mathrm{PO}+$ noni extract 350 $\mathrm{mg} / \mathrm{kg}$ ration supplemented with minerals $\mathrm{CuSO} 4$ and $\mathrm{ZnO}(P 4)$. Statistical analysis showed that the addition of noni fruit extract supplemented with copper and zinc minerals significantly increased the digestibility value of protein, dry matter, organic matter, metabolic energy value, and nitrogen retention in Sentul chickens. It was concluded that the addition of $250 \mathrm{mg} / \mathrm{kg}$ noni fruit extract supplemented with $\mathrm{CuSO} 4$ and $\mathrm{ZnO}$ minerals increased digestibility with a protein digestibility value of $67.52 \%$, dry matter digestibility of $70.12 \%$, digestibility of organic matter $75.14 \%$, metabolic energy value of $3460.79 \mathrm{kcal} / \mathrm{kg}$, and nitrogen retention with the addition of $150 \mathrm{mg} / \mathrm{kg}$ noni fruit extract supplemented with $\mathrm{CuSO} \neg 4$ and $\mathrm{ZnO} 81.45 \%$.

Keywords: Noni fruit, digestibility, ration

\section{PENDAHULUAN}

Ayam Sentul merupakan ayam lokal asli dari kabupaten Ciamis, Jawa Barat. Pertumbuhan yang cepat merupakan sifat genetik Ayam Sentul yang dapat dikembangkan sebagai ayam pedaging. Potensi genetik ini dapat tercapai dengan penambahan feed additive dalam ransum sebagai perangsang pertumbuhan. Antibiotik sebagai perangsang pertumbuhan (Growth Promotor) dilarang penggunaannya pada ternak setelah ditemukan bakteri yang resisten terhadap antibiotik dan akan menyebabkan penyakit yang serius pada manusia. Pemanfaatan bahan organik alamiah menjadi sangat penting diterapkan (Pangestu dkk., 2003; Adawiah dkk., 2007; Mushawwir dkk., 2019), dengan memanfaatkan sumber daya local (Tanuwiria dkk., 2007).

Pemilihan buah Mengkudu (Morinda citrifolia L.) didasarkan pada kandungan zatzat bioaktif yang terdiri dari senyawa fenolik, asam organik, dan alkaloid. Buah mengkudu mengandung proxeronin sebagai prekursor alami untuk xeronin. Xeronin merupakan alkaloid dari salah satu senyawa bioaktif buah mengkudu yang mampu memodifikasi struktur molekul protein. Penggunaan buah mengkudu dalam bentuk tepung pernah dilakukan namun tidak berpengaruh terhadap performa Ayam Sentul. Zat antinutrisi tannin yang terdapat pada buah mengkudu dapat mempengaruhi penyerapan zat makanan pada pencernaan Ayam Sentul. Ekstraksi pada buah mengkudu dilakukan agar diperoleh senyawa bioaktif yang diinginkan yaitu 
proxeronine dan mengurangi tannin yang terkandung pada ekstrak buah mengkudu.

Mineral tembaga berfungsi sebagai kofaktor beberapa macam enzim dan mineral seng berfungsi sebagai antimikroba di saluran pencernaan dan sebagai pemicu pertumbuhan. Penambahan mineral seng dan tembaga sebagai feed suplement pada ekstrak buah mengkudu diharapkan dapat membantu peran senyawa bioaktif dalam proses penyerapan zat nutrien dan meningkatkan bobot badan.

Keberhasilan pemanfaatan buah mengkudu dalam ransum ayam Sentul dapat diketahui dengan pengujian kecernaan yang dapat diukur salah satunya melalui nilai energi metabolis dan retensi nitrogen. Semakin tinggi kecernaan suatu pakan, maka semakin baik pula nutrien yang dimanfaatkan oleh ternak untuk kebutuhan produksi. Nilai Energi metabolis perlu diketahui karena nilai energi metabolis merupakan komponen yang dibutuhkan ternak untuk proses metabolisme dalam tubuh ternak dan retensi nitrogen yang menunjukkan kualitas ransum yang diberikan. Retensi nitrogen yang tinggi akan menghasilkan pertumbuhan yang tinggi pula, karena protein yang direntensi lebih besar. Berdasarkan uraian diatas, Penulis tertarik untuk melakukan penelitian mengenai "Peningkatan Pemanfaatan Ransum pada Ayam Sentul yang Diberi Ekstrak Buah Mengkudu dengan Suplementasi Tembaga dan Seng".

\section{METODE PENELITIAN}

Ayam percobaan yang digunakan dalam penelitian ini adalah anak Ayam Sentul umur sehari (DOC) sebanyak 100 ekor (unsexed) yang diperoleh dari Balai Pengembangan Perbibitan Ternak Unggas Jatiwangi Majalengka. Anak ayam dipelihara sampai umur 12 minggu. Bahan pakan penyusun ransum yang digunakan yaitu jagung kuning, dedak halus, tepung ikan, bungkil kedelai, tepung tulang, dan $\mathrm{CaCO}_{3}$. Bahan pakan diperoleh dari Poultry Shop Missouri Bandung. Susunan ransum penelitian dicantumkan pada Tabel 1 .
Kandungan nutrien ransum Ayam Sentul dicantumkan pada Tabel 2.

Pembuatan ekstrak mengkudu dilakukan dengan perendaman buah mengkudu dengan etanol $96 \%$ selama $2 \times 24$ jam. Hasil perendaman dimasukkan ke dalam alat evaporator dengan suhu $60{ }^{\circ} \mathrm{C}$ agar etanol dan ekstrak buah mengkudu terpisah. Hasil pemisahan etanol dengan ekstrak buah mengkudu diletakkan dalam oven dengan suhu $50{ }^{\circ} \mathrm{C}$ dengan hasil akhir berupa tepung.

Pembuatan ransum sesuai dengan formulasi dan dicampur agar homogen. Ekstrak buah mengkudu disuplementasikan dengan sejumlah mineral tembaga dan seng sesuai perlakuan. Selanjutnya dicampurkan dengan ransum basal untuk mendapatkan ransum perlakuan. Ransum yang sudah dicampur berbentuk mash dan kemudian dimasukkan ke dalam mesin pelleting.

Pengambilan sampel untuk kecernaan yaitu, ayam sentul berumur 12 minggu diberi ransum sesuai perlakuan. Metode untuk mendapatkan sampel feses mengikuti metode oleh Wiradisastra (1986) yaitu menggunakan teknik penyembelihan terhadap ayam percobaan dan mengambil sampel feses dari usus besar. Setelah ayam dipuasakan, ransum perlakuan diberikan kepada masing-masing ayam sebanyak 70 gram/ekor. Setelah 4 jam, ayam disembelih kemudian usus besar nya dikeluarkan untuk mendapatkan sampel feses. Percobaan ini menggunakan indikator internal (lignin) dari hasil analisis kandungan lignin dalam feses.

Pengambilan sampel untuk energi metabolis dan retensi nitrogen yaitu, ayam yang akan diuji yaitu ayam dengan bobot badan seragam serta diambil dari masingmasing unit perlakuan sebanyak satu ekor. Pemeliharaan dimulai saat ayam berumur lima minggu dan telah dipuasakan selama 24 jam, kemudian diberikan ransum yang sama dengan pemeliharaan sebelumnya. Ekskreta ayam dikumpulksan selama 24 jam. Ekskreta yang keluar disemprot dengan asam borat $5 \%$ setiap 3 jam untuk menghindari penguapan nitrogen. Ekskreta hasil penampungan dibersihkan dari bulu dan kotoran lainnya, kemudian ditimbang lalu dikeringkan. Ekskreta yang sudah kering dianalisis 
kandungan nitrogen dan energi brutonya dengan bomb calorimeter.
3. Kecernaan Protein

Protein adalah zat organik yang

Tabel 1. Susunan Ransum Penelitian

\begin{tabular}{lc}
\hline Bahan Pakan & Jumlah $(\%)$ \\
\hline Dedak Halus & 21,50 \\
Jagung Kuning & 56,00 \\
Tepung Ikan & 9,25 \\
Tepung Tulang & 0,75 \\
Bungkil Kedelai & 12,00 \\
$\mathrm{CaCO}_{3}$ & 0,50 \\
\hline
\end{tabular}

Tabel 2. Kandungan Nutrien dan Energi Metabolis Ransum Basal

\begin{tabular}{lcc}
\hline \multicolumn{1}{c}{ Kandungan nutrient } & Jumlah & Kebutuhan Ayam \\
\hline Energi Metabolisme (kkal/kg) & 2781 & $2750^{*}$ \\
Protein (\%) & 17,04 & $17^{*}$ \\
Lemak (\%) & 5,92 & $<8^{* *}$ \\
Serat Kasar (\%) & 4,51 & $<8^{* *}$ \\
Kalsium (\%) & 1,16 & $0,6^{* *}$ \\
Fosfor (\%) & 0,36 & $0,3^{* *}$ \\
Lysine (\%) & 1,21 & $0,65-90^{* *}$ \\
Methionin (\%) & 0,40 & $0,3-0,4^{* *}$ \\
\hline
\end{tabular}

Sumber : Hasil Analisis proksimat Laboratorium Nutrisi Ternak Ruminansia dan Kimia Makanan Ternak, Fakultas Peternakan, 2015

*Kebutuhan berdasarkan Widjastuti (1996)

**NRC (1994)

\section{Kecernaan Bahan Kering}

Kecernaan bahan kering diukur untuk mengetahui jumlah nutrient yang diserap oleh tubuh. Menggunakan analisis dan jumlah, baik dalam ransum maupun dalam feses, jumlah bahan kering yang dikonsumsi dan disekresikan dapat diketahui dan selisihnya adalah bahan jumlah bahan kering yang dicerna (Crampton dan Harris, 1969). Kecernaan bahan kering dapat dihitung menggunakan metode Schneider dan Flatt (1975).

2. Kecernaan Bahan Organik

Kecernaan bahan organik merupakan kecernaan zat-zat makanan yang meliputi komponen bahan organik seperti karbohidrat, protein, vitamin dan lemak (Gatenby, 1986). Kecernaan bahan organik dihitung menggunakan metode Schneider dan Flatt (1975) dan Ranjhan (1980.) mengandung karbon, hydrogen, nitrogen, oksigen, sulfur dan phosphor. Kecernaan protein dihitung menggunakan metode Schneider dan Flatt (1975) dan Ranjhan (1980).

4. Nilai Energi Metabolis

Nilai energi metabolis dihitung menggunakan rumus Sibbald dan Morse (1983)

5. Retensi Nitrogen

Retensi Nitrogen dihitung menggunakan metode Maynard dan Loosli (1969).

Penelitian dirancang menggunakan Rancangan Acak Lengkap (RAL), terdiri dari 5 macam perlakuan ransum. Perlakuan akan diulang sebanyak 4 kali dan setiap unit percobaan terdiri dari 5 ekor Ayam sentul. Perlakuan yang diberikan adalah tingkat pemberian ekstrak buah mengkudu yang di 
suplementasi mineral tembaga dan seng dalam ransum, yaitu :

$\mathrm{P} 0$ = Ransum Basal; P1= Ransum Basal + $50 \mathrm{mg} / \mathrm{kg}$ Ekstrak Buah Mengkudu yang disuplementasi mineral tembaga $0,064 \mathrm{mg} / \mathrm{kg}$ ransum dan seng $1,60 \mathrm{mg} / \mathrm{kg}$ ransum; P2=Ransum Basal + 150 mg/kg Ekstrak Buah Mengkudu yang disuplementasi mineral tembaga $0,192 \mathrm{mg} / \mathrm{kg}$ ransum dan seng 4,81 $\mathrm{mg} / \mathrm{kg}$ ransum; $\mathrm{P} 3=$ Ransum Basal +250 $\mathrm{mg} / \mathrm{kg}$ Ekstrak Buah Mengkudu yang disuplementasi mineral tembaga $0,32 \mathrm{mg} / \mathrm{kg}$ ransum dan seng $8,02 \mathrm{mg} / \mathrm{kg}$ ransum, dan $\mathrm{P} 4=$ Ransum Basal $+350 \mathrm{mg} / \mathrm{kg}$ Ekstrak Buah Mengkudu yang disuplementasi mineral tembaga $0,448 \mathrm{mg} / \mathrm{kg}$ ransum dan seng $11,23 \mathrm{mg} / \mathrm{kg}$ ransum.

\section{HASIL DAN PEMBAHASAN}

Pemanfataan ransum ayam Sentul yang diberi ekstak mengkudu yang disuplementasi dengan temabga dan seng, ditampilkan pada Tabel 3. Berdasarkan Tabel 3 nilai pemanfaatan ransum menunjukkan bahwa persentase kecernaan bahan kering (KcBK) pada perlakuan ransum basal ditambahkan $250 \mathrm{mg} / \mathrm{kg}$ Ekstrak Buah Mengkudu yang disuplementasi mineral tembaga $0,32 \mathrm{mg} / \mathrm{kg}$ ransum dan seng 8,02 $\mathrm{mg} / \mathrm{kg}$ ransum $(\mathrm{P} 3)$ nyata $(\mathrm{P}<0,05)$ lebih tinggi dari perlakuan lainnya. Hal tersebut menggambarkan bahwa semakin banyak jumlah ekstrak buah mengkudu yang disuplementasi mineral tembaga dan seng yang ditambahkan ke dalam ransum menghasilkan rataan nilai kecernaan bahan kering yang semakin tinggi, sejalan dengan hasil penelitian Derma (2014) bahwa pemberian ekstrak buah mengkudu 250 $\mathrm{mg} / \mathrm{kg}$ ransum memberikan performa terbaik pada Ayam Broiler.

Proxeronin dalam buah mengkudu membantu usus halus dalam proses penyerapan zat makanan. Djauhariya (2006) mengatakan bahwa proxeronin mempercepat penyerapan zat makanan ke dalam sistem pencernaan. Enzim Proxeroninase membantu merubah proxeronine menjadi xeronine di dalam usus halus (Heinicke, 1985. Xeronin mampu memodifikasi struktur molekul protein serta memiliki berbagai aktivitas biologis (Heinicke, 2001).

Ternak yang sehat akan membuat saluran pencernaan yang sehat pula, dengan itu dilakukan suplementasi mineral tembaga. Mineral tembaga berperan untuk membuat ternak sehat, sehingga saluran pencernaannya ikut sehat, dan membantu penyerapan zat makanan yang bagus. Protein yang merupakan salah satu unsur dari bahan kering, memiliki nilai penting dalam nilai kecernaan bahan kering, sehingga suplementasi mineral seng menjadi perlu. Mineral seng merupakan unsur pokok sebagai aktivator metalloenzim termasuk peptidase, untuk penyerapan protein (Anggorodi, 1995).

Proses penyerapan berbagai zat makanan terjadi di usus halus, sehingga kecernaan dipengaruhi oleh absorsbi zat makanan dalam mukosa usus (Cheeke, 2005). Pencampuran ekstrak buah mengkudu dan suplementasi mineral tembaga dan seng, menghasilkan penyerapan zat makanan dalam saluran pencernaan semakin baik, dan akan menghasilkan nilai kecernaan yang tinggi. Xeronin mampu memperluas lubang usus halus sehingga zat makanan dapat lebih banyak terserap (Djauhariya, 2003). Suplementasi mineral seng dalam ransum sebagai salah satu unsur pokok aktivator metalloenzim termasuk peptidase untuk penyerapan protein akan membantu dalam meningkatkan nilai kecernaan bahan kering. Sejalan dengan yang dikemukakan Abun, dkk. (2003), Faktor-faktor yang ikut mempengaruhi nilai kecernaan bahan kering ransum adalah tingkat proporsi bahan pakan dalam ransum, komposisi kimia, tingkat protein ransum, persentase lemak dan mineral. Salah satu yang mempengaruhi ternak dapat mencerna pakan dengan baik yaitu saluran pencernaan yang sehat dengan ternak yang sehat, dengan suplementasi mineral tembaga saluran pencernaan ternak akan semakin baik. Hal ini sesuai dengan Cromwell (1991), Mekanisme respons penambahan $\mathrm{Cu}$ pada perbaikan penampilan ternak adalah proses penghambatan aktivitas mikroorganisme penyebab penyakit sehingga 
mempengaruhi kesehatan ternak dan terjadi peningkatan pertumbuhan.

Berdasarkan Tabel 3 nilai pemanfaatan ransum menunjukkan bahwa persentase kecernaan bahan organik (KcBO) pada perlakuan ransum basal ditambahkan $250 \mathrm{mg} / \mathrm{kg}$ Ekstrak Buah Mengkudu yang disuplementasi mineral tembaga $0,32 \mathrm{mg} / \mathrm{kg}$ ransum dan seng $8,02 \mathrm{mg} / \mathrm{kg}$ ransum $(\mathrm{P} 3)$ nyata $(\mathrm{P}<0,05)$ lebih tinggi dari perlakuan lainnya. Hal tersebut menggambarkan bahwa semakin banyak jumlah ekstrak buah mengkudu yang disuplementasi mineral tembaga dan seng yang ditambahkan ke dalam ransum menghasilkan rataan nilai kecernaan bahan organik yang semakin tinggi, sejalan dengan hasil penelitian Derma (2014) bahwa pemberian ekstrak buah mengkudu $250 \mathrm{mg} / \mathrm{kg}$ ransum memberikan performa terbaik pada Ayam Broiler. bahan kering terdiri atas bahan organik sehingga faktor-faktor yang mempengaruhi tinggi rendahnya kecernaan bahan kering akan berpengaruh juga terhadap tinggi rendahnya bahan organik.

Berdasarkan Tabel 3 nilai pemanfaatan ransum menunjukkan bahwa persentase kecernaan protein $(\mathrm{KcPK})$ pada perlakuan ransum basal ditambahkan 250 $\mathrm{mg} / \mathrm{kg}$ Ekstrak Buah Mengkudu yang disuplementasi mineral tembaga $0,32 \mathrm{mg} / \mathrm{kg}$ ransum dan seng $8,02 \mathrm{mg} / \mathrm{kg}$ ransum $(\mathrm{P} 3)$ nyata $(\mathrm{P}<0,05)$ lebih tinggi dari perlakuan lainnya. Hal tersebut menggambarkan bahwa semakin banyak jumlah ekstrak buah mengkudu yang disuplementasi mineral tembaga dan seng yang ditambahkan ke dalam ransum menghasilkan rataan nilai kecernaan protein yang semakin tinggi, sejalan dengan hasil penelitian Derma (2014)

Tabel 3. Nilai Pemanfaatan Ransum

\begin{tabular}{cccccc}
\hline Perlakuan & KcBK $(\% 0$ & KcBO $(\%)$ & KcPK $(\%)$ & $\begin{array}{c}\text { Energi Metabolis } \\
(\mathrm{kkal} / \mathrm{kg})\end{array}$ & $\begin{array}{c}\text { Retensi } \\
\text { Nitrogen }(\%)\end{array}$ \\
\hline P0 & $63,69^{\mathrm{ab}}$ & $68,99^{\mathrm{b}}$ & $62,23^{\mathrm{a}}$ & $3106,59^{\mathrm{a}}$ & $74,07^{\mathrm{ab}}$ \\
P1 & $61,80^{\mathrm{a}}$ & $65,54^{\mathrm{a}}$ & $60,54^{\mathrm{a}}$ & $3218,78^{\mathrm{a}}$ & $79,15^{\mathrm{bc}}$ \\
P2 & $64,85^{\mathrm{b}}$ & $68,50^{\mathrm{b}}$ & $61,26^{\mathrm{a}}$ & $3232,24^{\mathrm{a}}$ & $81,45^{\mathrm{c}}$ \\
P3 & $70,12^{\mathrm{c}}$ & $75,14^{\mathrm{c}}$ & $67,52^{\mathrm{b}}$ & $3460,79^{\mathrm{b}}$ & $78,52^{\mathrm{bc}}$ \\
P4 & $70,11^{\mathrm{c}}$ & $74,63^{\mathrm{c}}$ & $62,27^{\mathrm{a}}$ & $3024,05^{\mathrm{a}}$ & $71,11^{\mathrm{a}}$ \\
\hline
\end{tabular}

Keterangan : Huruf yang sama pada kolom yang berbeda menunjukkan pengaruh perlakuan tidak berbeda nyata $(\mathrm{P}>0,05)$; KcBK: Kecernaan Bahan Kering; KcBO: Kecernaan Bahan Organik; KcPK: Kecernaan Protein Kasar.

Kecernaan yang tinggi menunjukkan zat-zat pakan yang diserap tubuh semakin tinggi (Irawan, 2012). Sama halnya seperti pada bahan organik, proxeronin dan xeronin membantu dalam proses penyerapan zat makanan dalam saluran pencernaan ternak.

Hasil penambahan ekstrak buah mengkudu yang disuplementasi mineral tembaga dan seng terhadap nilai kecernaan bahan organik akan sama dengan nilai kecernaan bahan kering. Hal ini dikemukakan oleh Sutardi (1980), Peningkatan kecernaan bahan organik sejalan dengan meningkatnya kecernaan bahan kering, karena sebagian besar komponen bahwa pemberian ekstrak buah mengkudu $250 \mathrm{mg} / \mathrm{kg}$ ransum memberikan performa terbaik pada Ayam Broiler.

Xeronin mampu memodifikasi struktur molekul protein sehingga saat protein seperti enzim atau reseptor tidak dalam konformasi yang sesuai, xeronin akan berinteraksi dengan protein dan membuatnya terlipat sehingga menjadi konformasi yang tepat dan berfungsi dengan baik (Heinicke, 2001). Saluran pencernaan ternak yang sehat karena mineral tembaga, akan membuat penyerapan semakin baik. Mineral seng juga merupakan unsur pokok sebagai aktivator metalloenzim termasuk peptidase, untuk 
penyerapan protein (Anggorodi, 1995). Proses penyerapan berbagai zat makanan terjadi di usus halus, sehingga kecernaan dipengaruhi oleh absorsbi zat makanan dalam mukosa usus (Cheeke, 2005).

Usus halus memiliki dinding yang tebal dapat mengakibatkan protein yang akan dirombak menjadi pecah karena terlalu lama dalam usus halus dan belum dirombak. Xeronin membantu proses penyerapan menjadi lebih cepat karena mampu memperluas lubang usus halus sehingga zat makanan dapat lebih banyak terserap dan tidak lama dalam usus halus (Djauhariya, 2003). Suplementasi mineral seng dalam ransum sebagai salah satu unsur pokok aktivator metalloenzim termasuk peptidase untuk penyerapan protein sehingga akan semakin banyak protein yang bisa diserap dalam usus halus. Sejalan dengan yang dikemukakan oleh Widodo, dkk. (2013), Tinggi rendahnya nilai kecernaan tergantung pada bahan penyusun ransum dan banyaknya protein yang masuk dalam saluran pencernaan.

Rendahnya kandungan protein dalam feses juga mempengaruhi nilai kecernaan. Menurut Schneider dan Flatt (1975), Zat makanan yang terdapat di dalam feses dianggap zat makanan yang tidak tercerna sehingga sedikit kandungan protein kasar dalam feses maka nilai kecernaannya semakin baik. Salah satu yang mempengaruhi ternak dapat mencerna pakan dengan baik yaitu saluran pencernaan yang sehat dengan ternak yang sehat, dengan suplementasi mineral tembaga saluran pencernaan ternak akan semakin baik. Hal ini sesuai menurut Cromwell (1991), Mekanisme respons penambahan $\mathrm{Cu}$ pada perbaikan penampilan ternak adalah proses penghambatan aktivitas mikroorganisme penyebab penyakit sehingga mempengaruhi kesehatan ternak dan terjadi peningkatan pertumbuhan.

Nilai pemanfaatan ransum menyatakan Nilai Energi Metabolis (EMn) perlakuan ransum lainnya lebih rendah dibandingkan dengan ransum basal ditambahkan $250 \mathrm{mg} / \mathrm{kg}$ ekstrak buah mengkudu yang disuplementasi mineral tembaga $0,32 \mathrm{mg} / \mathrm{kg}$ ransum dan seng 8,02 $\mathrm{mg} / \mathrm{kg}$ ransum (P3). P3 menggunakan ransum dengan penambahan pakan imbuhan ekstrak buah mengkudu sebesar $250 \mathrm{mg} / \mathrm{kg}$ ransum yang disuplementasi mineral tembaga $0,32 \mathrm{mg}$ dan seng 8,02 $\mathrm{mg}$ meningkatkan nilai energi metabolis ayam Sentul. Hasil ini sesuai dengan Penelitian Derma (2014) yang menyatakan bahwa pemberian ekstrak buah mengkudu 250 $\mathrm{mg} / \mathrm{kg}$ ransum memberikan performa terbaik pada Ayam Broiler.

Nilai energi metabolis berbanding lurus dengan kecernaan sehingga apabila kecernaan meningkat maka nilai energi metabolis akan meningkat. Senyawa bioaktif proxeronin yang terkandung dalam ekstrak buah mengkudu bekerja di saluran pencernaan. Sebelum senyawa proxeronin diubah menjadi xeronin oleh enzim proxeroninase, senyawa proxeronin membantu proses penyerapan zat makanan di dalam usus halus lalu setelah senyawa proxeronin diubah menjadi senyawa xeronin akan meningkatkan proses penyerapan nutrien sehingga nilai energi metabolis dan kecernaan dalam usus halus akan meningkat. Djauhariya (2006) menyatakan bahwa proxeronin mempercepat penyerapan zat makanan ke dalam sistem pencernaan dan menyelaraskan kerja sel dalam tubuh (Mushawwir et al., 2017 dan 2018) dan ditambahkan oleh Sridevi (2013) yang menyatakan bahwa xeronin mengaktifkan protein perifer hormon insulin dan membantu proses penyerapan glukosa sehingga kecernaan pun meningkat. Energi metabolis akan meningkat apabila kecernaan meningkat, hal ini sesuai dengan pendapat Tillman (1994) bahwa kecernaan akan mempengaruhi nilai energi metabolis.

Peran mineral tembaga dalam saluran pencernaan adalah menghambat aktifitas mikroorganisme sehingga kondisi usus sehat dan mineral seng berfungsi sebagai kofaktor berbagai macam enzim salah satunya adalah enzim protease yang berfungsi untuk memecah molekul protein menjadi asam amino sehingga kecernaan protein akan meningkat. Hal tersebut sesuai dengan pernyataan Cromwell (1991) bahwa mineral tembaga menghambat aktivitas 
mikroorganisme penyebab penyakit sehingga mempengaruhi kesehatan saluran pencernaan ternak dan terjadi peningkatan pertumbuhan (Mushawwir dan Latipudin, 2012). Mineral seng di dalam tubuh ternak akan diserap oleh duodenum dan dibawa ke plasma darah sehingga membantu proses metabolisme. Hal tersebut sesuai dengan pendapat NRC (1994) bahwa sebagai sistem enzim, mineral seng berperan dalam metabolisme karbohidrat, sintesis protein, dan metabolisme asam nukleat.

Berdasarkan Tabel 3 nilai pemanfaatan ransum diketahui bahwa Retensi Nitrogen (RN) ransum basal ditambahkan $150 \mathrm{mg} / \mathrm{kg}$ ekstrak buah mengkudu yang disuplementasi mineral tembaga $0,192 \mathrm{mg} / \mathrm{kg}$ ransum dan seng 4,81 $\mathrm{mg} / \mathrm{kg}$ ransum $(\mathrm{P} 2)$ nyata lebih tinggi dari perlakuan ransum lainnya. Hasil ini memperlihatkan bahwa retensi nitrogen meningkat pada perlakuan yang ditambahkan $50 \mathrm{mg} / \mathrm{kg}$ ekstrak buah mengkudu dan perlakuan yang ditambahkan $150 \mathrm{mg} / \mathrm{kg}$ ekstrak buah mengkudu tetapi menurun pada perlakuan yang ditambahkan $250 \mathrm{mg} / \mathrm{kg}$ ekstrak buah mengkudu dan perlakuan yang ditambahkan $350 \mathrm{mg} / \mathrm{kg}$ ekstrak buah mengkudu. Wahju (2004), menyatakan bahwa rata-rata nitrogen yang diretensi oleh broiler adalah $67 \%$ dari ransum yang dikonsumsi. Nilai retensi nitrogen yang didapatkan dalam penelitian ini $(71,11 \%$ $81,45 \%$ ) lebih tinggi dari $67 \%$.

Banyak faktor yang dapat mempengaruhi nilai retensi nitrogen. Menurut Sibbald (1981) dan Tanuwiria $\left(2007_{\mathrm{a}, \mathrm{b}}\right)$ nilai retensi nitrogen akan bervariasi untuk masing-masing unggas, tergantung dari kemampuan unggas untuk menahan nitrogen di dalam tubuh unggas dan tidak dikeluarkan sebagai nitrogen dalam urin. Wahju (2004) juga berpendapat bahwa tingkat retensi nitrogen bergantung pada nilai energi metabolis dan konsumsi nitrogen.

Kenaikan retensi nitrogen dapat terjadi karena peran senyawa bioaktif proxeronin yang membantu proses penyerapan zat makanan di saluran pencernaan dan dibantu oleh peran mineral tembaga yang berfungsi sebagai antimikroba dan mineral seng sebagai kofaktor enzim protease yang mampu memecah protein menjadi molekul yang lebih sederhana sehingga meningkatkan retensi nitrogen.

Meskipun perlakuan yang ditambahkan $250 \mathrm{mg} / \mathrm{kg}$ ekstrak buah mengkudu memiliki nilai energi metabolis paling tinggi tidak menentukan retensi nitrogen paling tinggi pula. Perlakuan yang ditambahkan $150 \quad \mathrm{mg} / \mathrm{kg}$ ekstrak buah mengkudu mendapatkan retensi nitrogen yang paling tinggi karena retensi nitrogen berbanding lurus dengan konsumsi nitrogen dan berbanding terbalik dengan nitrogen ekskreta. Nilai nitrogen yang terkandung dalam ekskreta rata-rata adalah $2,45 \%$ untuk perlakuan yang ditambahkan $150 \mathrm{mg} / \mathrm{kg}$ ekstrak buah mengkudu, sedangkan untuk perlakuan ransum basal $2,89 \%$, perlakuan yang ditambahkan $50 \mathrm{mg} / \mathrm{kg}$ ekstrak buah mengkudu $2,85 \%$, perlakuan yang ditambahkan $250 \mathrm{mg} / \mathrm{kg}$ ekstrak buah mengkudu $2,74 \%$, dan perlakuan yang ditambahkan $350 \mathrm{mg} / \mathrm{kg}$ ekstrak buah mengkudu $2,80 \%$. Semakin tinggi nitrogen yang diretensi dalam tubuh unggas, maka jumlah nitrogen dalam feses dan urin semakin rendah (NRC, 1994).

\section{SIMPULAN DAN SARAN}

Semakin banyak ekstrak buah mengkudu yang disuplementasi mineral tembaga dan seng yang ditambahkan kedalam ransum menghasilkan rataan nilai kecernaan bahan kering, bahan organik, protein, nilai energi metabolis, dan retensi nitrogen yang semakin meningkat, dimana nilai kecernaan bahan kering, bahan organik, dan protein tertinggi diperoleh dari perlakuan ransum basal $+250 \mathrm{mg} / \mathrm{kg}$ Ekstrak Buah Mengkudu yang disuplementasi mineral tembaga $0,32 \mathrm{mg} / \mathrm{kg}$ ransum dan seng 8,02 $\mathrm{mg} / \mathrm{kg}$ ransum. Penggunaan ransum basal yang ditambahkan ekstrak buah mengkudu, disarankan menggunakan $250 \mathrm{mg} / \mathrm{kg}$ ekstrak buah mengkudu yang disuplementasi mineral tembaga $0,32 \mathrm{mg} / \mathrm{kg}$ ransum dan seng 8,02 $\mathrm{mg} / \mathrm{kg}$ ransum agar meningkatkan pemanfaatan ransum pada ayam sentul. 


\section{UCAPAN TERIMA KASIH}

Ucapan Terima Kasih disampaikan kepada seluruh pihak yang telah membantu penelitian ini, khususnya kepada tim penelitian Academic Leadership Grant (ALG) Prof. Dr. Tuti Widjastuti yang telah memfasilitasi dan mendanai penelitian ini.

\section{DAFTAR PUSTAKA}

Abun, D. Rusmana dan N. P. Indriani. 2003. Penentuan kecernaan ransum mengandung ampas umbi Garut (maranta arundinacea linn.) pada ayam broiler dengan metode pemotongan. J. Bionatura. 5:227-238.

Adawiah, A., T. Sutardi, T. Toharmat, W. Manalu, N. Ramli dan U.H. Tanuwiria, 2007. Respons terhadap suplementasi sabun mineral dan mineral organik serta kacang kedelai sangrai pada indikator fermentabilitas ransum dalam rumen domba. Media Peternakan. 30:62-69.

Anggorodi, R. 1995. Nutrisi Aneka Ternak Unggas. Gramedia Pustaka Utama. Jakarta.

Cheeke, P. R. 2005. Applied Animal Nutrition, Feeds and Feeding. 3rd ed, Pearson Prentice Hall, New Jersey.

Crampton, E. W. dan L. E. Harris. 1969. Applied Animal Nutrition. W. H. Freeman and Company. San Fransisco.

Cromwell, G.L. 1991. Antimicrobial Agents. Di dalam : E. R. Miller, D. E. Miller, dan A. J. Lewis (Ed.) Swine Nutrition. Butterworth-Heinemann Publishing, Boston, MA.

Derma, F. 2014. Pengaruh Pemberian Ekstra Campuran Mengkudu dan Daun Kayu Manis Sebagai Feed Aditif terhadap Performa Ayam Broiler. Jurnal. Fakultas Peternakan Universitas Andalas. Padang.

Djauhariya, E. 2003. Mengkudu (Morinda citrifolia L.) tanaman obat potensial. J. Perkembangan Teknologi TROL. $\mathrm{XV}: 21-26$.
Djauhariya, E. 2006. Karakterisasi morfologi dan mutu buah mengkudu. Buletin Plasma Nutfah. 12:1-8.

Gatenby, R. M. 1986. Sheep Production in The Tropics and Sub-tropics. Longman, London-New York.

Heinicke, RM . 2001. The xeronine system a new cellular mechanism that explains the health promoting action of Noni and Bromelain.

Heinicke, R.M. 1985. Xeronine: a new alkaloid, useful in medical, fodood and industrial fields. United States Patent (US4543212), USA.

Irawan, I., D, Sunarti dan L. D. Mahfudz. 2012. Pengaruh pemberian pakan bebas pilih terhadap kecernaan protein burung puyuh (Cotunix cotunix japonica). Anim. Agliculture J. 1:238-245.

Maynard, L. A., dan J.K. Loosli. 1969. Animal Nutrition. Sixth Edition. McGraw-Hill. New Delhi.

Mushawwir, A. dan D. Latipudin. 2012. Respon fisiologi thermoregulasi ayam ras petelur fase grower dan layer. Proseding seminar zootechniques for Indogeneous resources development, ISAA Fakultas Petenakan Universitas Diponegoro. Proceeding of National Seminar on Zootechniques. 1:23-27.

Mushawwir, A., U. H. Tanuwiria, K.A. Kamil, L. Adriani and R. Wiradimadja. 2017. Effects of volatile oil of garlic on feed utilization, blood biochemistry and performance of heat-stressed japanese quail. Asian J. of Poult. Sci. 11:83-89.

Mushawwir, A., U.H. Tanuwiria, Kurnia Kamil, L. Adriani, R. Wiradimadja, and N. Suwarno. 2018. Evaluation of haematological responses and blood biochemical parameters of heat-stressed broilers with dietary supplementation of Javanese Ginger powder (Curcuma xanthorrhiza) and garlic extract (Allium sativum). International J. of Poult. Sci . 17:452-458. 
Mushawwir, A., N. Suwarno dan A.A. Yulianti. 2019. Profil Malondialdehyde (MDA) dan Kreatinin Itik Fase Layer yang Diberi Minyak Atsiri Garlic Dalam Kondisi Cekaman Panas. J. Ilmu dan Industri Peternakan $5: 1-11$.

National Research Council. 1994. Nutrien Requirements of Poultry. $9^{\text {th }}$ ed. National Academy Press, Washington, DC.

Pangestu, E., T. Toharmat dan U.H. Tanuwiria. 2003. Nilai nutrisi ransum berbasis limbah industri pertanian pada sapi perah laktasi. J. Indon. Trop. Anim. Agric. 28:166-171.

Ranjhan, S. K. 1980. Animal Nutrition in the Tropics. Vikas Publishing Hause P\&T Ltd., New Delhi.

Schneider, B. H. dan W. P. Flatt. 1975. The Evaluation Of Feeds Through Digestibility Experiment. The University Of Georgia Press. New York.

Sibbald, I.R. 1981. Metabolic plus endogenous energy and nitrogen losses of adult cockerels : the corretion used in bioassay for true metabolizable energy. International Development Reseach Center. Canada.

Sibbald, I.R. and M.S. Wolynetz. 1983. The effect of level Intake on Metaboliszable Energy Values Measured With Adult Rootger. Poultry Sci. 64:127-138.

Sridevi, N., C.S. Sasikumar and K.M. Cherian. 2013. Morinda Citrifolia (Noni) - a detailed review. Int. J. Univers. Pharm. Bio. Sci. 23:142-177.

Sutardi, T. 1980. Landasan Ilmu Nutrisi Jilid 1. Departemen Ilmu Makanan Ternak. Fakultas Pertanian IPB. Bogor.

Tanuwiria, U.H. 2007a. Proteksi protein tepung ikan oleh berbagai sumber tannin dan pengaruhnya terhadap fermentabilitas dan kecernaannya (in vitro). J. Agroland. 14:56-60.

Tanuwiria, U.H., 2007b. Efek suplementasi kompleks mineral-minyak dan mineral-organik dalam ransum terhadap kecernaan ransum, populasi mikroba rumen dan performa produksi domba jantan. Prosiding Seminar Nasional dan Kongres Asosiasi Ahli Nutrisi. AINI. 1:23-27. Tanuwiria, U.H., A. Mushawwir dan A. Yulianti. 2007. Potensi pakan serat dan daya dukungnya terhadap populasi ternak ruminansia di wilayah kabupaten Garut. J. Ilmu Pertanian. 7:117-127.

Tillman. A.D., H. Hartadi., S. Reksohadiprojo., S. Prawirokusumo, dan S. Lebdosoekojo. 1984. Ilmu Makanan Ternak Dasar. Gadjah Mada University Press, Yogyakarta.

Wahju. 2004. Ilmu Nutrisi Unggas. Yogyakarta: Universitas Gajah Mada Press

Widjastuti, T. 1996. Penentuan Efisiensi Penggunaan Protein, Kebutuhan protein dan Energi Untuk Pertumbuhan dan Produksi Telur Ayam Sentul pada Kandang Sistem Cage Litter. Disertasi. Program Pascasarjana Unpad Bandung.

Widodo, A. R., H. Setiawan, Sudiyono, Sudibya dan R. Indreswari. 2013. Kecernaan nutrient dan performan puyuh (Coturnix coturnix japonica) jantan yang diberi ampas tahu fermentasi dalam ransum. Tropical Anim. Husbandry. 2:51-57.

Wiradisastra, M.D.H. 1986. Efektivitas Keseimbangan Energi dan Asam Amino dan Efisiensi Absorpsi dalam Menentukan Persyaratan Kecepatan Tumbuh Ayam Broiler. Disertasi, Institut Pertanian Bogor, Bogor. 